www.czasopisma.marszalek.com.pl/pl/10-15804/npw

\author{
Arkadiusz Żukowski \\ Uniwersytet Warmińsko-Mazurski \\ ORCID ID: https://orcid.org/0000-0003-3413-9492
}

\title{
Sprawozdanie z XXV Światowego Kongresu Politologicznego, Brisbane, 21-25 lipca 2018 r.
}

Report from the 25th World Congress of Political Science, Brisbane, July 21-25, 2018

Отчет о XXV Всемирном конгрессе Международной ассоциации политической науки, Брисбен, 21-25 июля 2018 г.

W dniach 21-25 lipca 2018 r. w Brisbane w Australii odbył się 25. Jubileuszowy Światowy Kongres Politologiczny (25th World Congress of International Political Science Association). Zgromadził on ponad 2 tys. naukowców z całego świata (spodziewano się 2,4 tys. naukowców). Z 2351 zarejestrowanych uczestników 2239 wzięło udział w Kongresie (w porównaniu do Światowego Kongresu IPSA w Poznaniu w 2016 r. z 2729 osób zarejestrowanych uczestniczyło w nim 2239 badaczy). Kongres zgromadził badaczy z 84 krajów (na Światowym Kongresie IPSA w Poznaniu w 2016 r. - reprezentanci 92 krajów). Program Kongresu obejmował cztery sesje plenarne, sześć sesji specjalnych, 1 sesję z wręczaniem nagród i 516 paneli (łączna liczba propozycji paneli wyniosła 936). Temat wiodący Kongresu brzmiał: „Borders and Margins” („Granice i skrajności”) w polityce ${ }^{1}$.

12018 Post-Congress Report: 25th IPSA World Congress in Brisbane 2018. (2018). Montreal 2018, p. 3, 10. 
Polskie politolożki i polscy politolodzy regularnie uczestniczą w Światowych Kongresach IPSA. Tak było od początku członkostwa Polski w IPSA, chociaż do lat 90 . XX w. były to jednostki. Ten krótki raport, głównie w ujęciu ilościowym, ma dać wstępny, a przy tym syntetyczny obraz zaangażowania polskiej politologii w Kongres i materiał do dyskusji. Dotychczas nie praktykowano w Polskim Towarzystwie Nauk Politycznych i w Komitecie Nauk Politycznych Polskiej Akademii Nauk formy pisemnej raportów/sprawozdań ze światowych kongresów politologicznych.

Bazując na programie Kongresu, jako przewodniczący, współprzewodniczący, dyskutanci i referenci, swój akces do udziału w nim zgłosiły 62 osoby z Polski. Po raz pierwszy wśród badaczy z Polski były osoby z zagranicy, które zgłosiły się na Kongres z afiliacją polskich uczelni i instytucji naukowych ${ }^{2}$. Ostatecznie 49 badaczy z Polski zostało oficjalnie zarejestrowanych na Kongres. Nie wszystkim udało się przybyć na Kongres. Na podstawie danych Sekretariatu IPSA ${ }^{3}$ na Kongres przybyło i wzięło aktywny udział 48 badaczy z Polski (zob. Załącznik nr 1). W porównaniu do reprezentacji z innych krajów Polska delegacja pod względem liczebności była znacząca i plasowała się wraz z Brazylią na jedenastym miejscu (Polska - 48 uczestników z 49 zarejestrowanych, Brazylia - odpowiednio 48 z 59). Zdecydowanie najliczniejszą reprezentację miała Australia (560 uczestników z 591 zarejestrowanych), a w dalszej kolejności: USA - 191 z 208, Japonia - 151 ze 153, Indie - 99 z 111, Wielka Brytania - 98 ze 108, Korea Południowa - 94 ze 100, Niemcy - 89 z 94, Kanada 87 z 94, Nowa Zelandia - 52 z 55 i Tajwan (Republika Chińska) - 50 z 52. Stosunkowo mało liczne delegacje przybyły z krajów Europy Zachodniej: Austria - 4 uczestników z 5 zarejestrowanych, Belgia - 26 z 27, Dania - 14 z 14, Finlandia - 13 z 13, Francja - 29 z 37, Włochy - 6 z 11, Holandia - 18 z 19, Norwegia - 23 z 24, Szwecja - 17 z 17. Z kolei udział w Kongresie badaczy z krajów byłego bloku wschodniego kształtował się następująco: Bułgaria - 1 z 1, Chorwacja - 12 z 13, Czechy

2 Referaty zgłosili następujący badacze: David A. Jones - Uniwersytet Warszawski, Hanzhen Liu - Akademia Biznesu i Finansów Vistula, Kateryna Pryshchepa - Kolegium Europejskie w Natolinie, Olga Zelinska - Instytut Filozofii i Socjologii, Polska Akademia Nauk oraz Ivan Fomin - Uniwersytet Mikołaja Kopernika w Toruniu.

3 Za dane z Sekretariatu IPSA w Montrealu chciałbym podziękować: Adrienne Jung, Aubertowi Descôteaux i Mathieu St-Laurent. 
- 18 z 19, Estonia 2 z 2, Węgry - 4 z 4, Kazachstan - 4 z 4, Litwa - 3 z 3, Mołdawia - 1 z 1, Rumunia - 5 z 5, Rosja - 38 z 41, Serbia - 3 z 3, Słowacja - 4 z 4 , Słowenia - 2 z 5, Ukraina - 4 z 4 .

Pod względem zróżnicowania według stopni i tytułów naukowych oraz zawodowych najliczniejszą grupę badaczy z Polski stanowili samodzielni pracownicy - 25, a następnie doktorzy - 15 oraz magistrowie i doktoranci - 6. Wśród samodzielnych pracowników przeważali doktorzy habilitowani, a profesorów tytularnych uczestniczyło w Kongresie 7. W kontekście deklarowanej afiliacji najliczniejszą reprezentację z Polski stanowili pracownicy Uniwersytetu Warszawskiego $(12+3)^{4}$, a następnie Uniwersytetu Adama Mickiewicza w Poznaniu (9), Uniwersytetu Jagiellońskiego (4), Uniwersytetu Wrocławskiego (3), Uniwersytetu Gdańskiego (3), Uniwersytetu Jana Kochanowskiego w Kielcach (3) i Polskiej Akademii Nauk (3). Po jednym przedstawicielu miały na Kongresie następujące uczelnie: SWPS Uniwersytet Humanistycznospołeczny, Collegium Civitas, Uniwersytet Marii-Curie Skłodowskiej, Uniwersytet Mikołaja Kopernika w Toruniu, Kolegium Europejskie w Natolinie, Uniwersytet Łódzki, Uniwersytet w Białymstoku i Uniwersytet Warmińsko-Mazurski w Olsztynie. Kobiety stanowiły 44\% uczestników Kongresu z Polski (średnia dla Kongresu wyniosła 42\%).

Po raz pierwszy na Kongresie IPSA monitorowano obecność uczestników i ich udział w panelach, posiedzeniach zebraniach.

W kontekście władz struktur organizacyjnych i instytucjonalnych polskiej politologii należy zaznaczyć, że znacząca była reprezentacja władz Polskiego Towarzystwa Nauk Politycznych ${ }^{5}$. Komitet Nauk Politycznych PAN reprezentował jego przewodniczący ${ }^{6}$. Gorzej przedstawiała się reprezentacja politologów z władz rektorskich, dziekańskich i instytutowych

4 Dwie osoby związane z Uniwersytetem Warszawskim miały afiliację Fundacji Instytutu Nauki o Polityce (Paulina Kalina i Jarosław Szczepański), a jeden urlopowany pracownik Uniwersytetu Warszawskiego w związku z pełnieniem funkcji ambasadora RP w Mołdawii nie podał żadnej afiliacji (Bartłomiej Zdaniuk).

5 Władze Zarządu Głównego PTNP były reprezentowane przez prezesa: Arkadiusza Żukowskiego, wiceprezesów: Agnieszkę Kasińską-Metrykę, Andrzeja Stelmacha oraz członka: Przemysława Żukiewicza. Poza tym przez członków Komisji Rewizyjnej: Tadeusza Dmochowskiego, Magdalenę Musiał-Karg.

6 Przewodniczący: Tadeusz Wallas. 
polskich uczelni ${ }^{7}$. Należy wspomnieć, że niektóre piastowane funkcje dublowały się.

Jak na każdy Światowy Kongres IPSA Polskie Towarzystwo Nauk Politycznych wybrało oficjalną delegację, która składała się z trzech delegatów i trzech ich zastępców ${ }^{8}$. Polska, podobnie jak: Stany Zjednoczone, Wielka Brytania, Niemcy, Kanada, Japonia i Rosja w Radzie IPSA (IPSA Council) ma największą liczbę delegatów - trzech, pozostałe towarzystwa krajowe mają po dwóch, a najczęściej po jednym delegacie w tej Radzie. Taką sytuację dotyczącą liczby delegatów należy uznać za wielce satysfakcjonującą.

Delegaci (2) i ich zastępcy (1) uczestniczyli w obradach ogólnych Rady IPSA oraz w wyborach prezydenta i członków Komitetu Wykonawczego IPSA. Ponadto prezes PTNP wziął udział w posiedzeniu prezesów komitetów krajowych towarzystw nauk politycznych.

Przedstawiciel Polski (Polskie Towarzystwo Nauk Politycznych) tradycyjnie jest wybierany do Komitetu Wykonawczego IPSA ${ }^{9}$. Przed oficjalnym rozpoczęciem Kongresu w Brisbane w ostatnim posiedzeniu ustępującego Komitetu Wykonawczego uczestniczyła A. Kasińska-Metryka. W wyborach podczas Kongresu na nowego członka Komitetu Wykonawczego został wybrany A. Żukowski. Po Kongresie wziął udział w pierwszym posiedzeniu nowo wybranego Komitetu Wykonawczego IPSA, gdzie m.in. został wybrany do dwóch podkomitetów: Wolności Akademickiej (Academic Freedom) oraz Uczestnictwa i Członkostwa (Participation and Membership).

Nowym prezydentem IPSA została Marianne Kneuer z Niemiec. Ponadto w skład Komitetu Wykonawczego weszli: Martin d’Alessandro (Argentyna), Yasmeen Abu-Laban (Kanada), Olivier Nay (Francja), Ferdinand Müller-Rommel (Niemcy), Gujja Gopal Reddy (Indie), Simona Piattoni (Włochy), Yuko Kasuya (Japonia), Eui Young Kim (Korea), Jesus A. Rodriguez Alonso

7 Rektorzy i prorektorzy: Tadeusz Wallas; dziekani: Tadeusz Dmochowski, Andrzej Stelmach; dyrektorzy Instytutów: Mikołaj Cześnik (socjolog polityki), Agnieszka Kasińska-Metryka, Arkadiusz Żukowski.

8 Delegaci: Agnieszka Kasińska-Metryka, Marceli Burdelski, Arkadiusz Żukowski; zastępcy delegatów: Andrzej Stelmach, Adam Szymański, Tadeusz Wallas.

9 Od lat 90. XX w. członkami Komitetu Wykonawczego IPSA byli, w kolejności chronologicznej, Krzysztof Pałecki, Teresa Sasińska-Klas, Roman Bäcker, Agnieszka Kasińska-Metryka. 
(Meksyk), Hilmar Rommetvedt (Norwegia), Christopher Isike (Afryka Południowa), Pablo Oñate (Hiszpania), Hasret Dikici Bilgin (Turcja), Umut Korkut (Wielka Brytania) i Rodney Hero (USA) ${ }^{10}$.

Należy odnotować fakt ponownych wyborów, jak i reelekcji Polek i Polaków w wyborach do władz Komitetów Badawczych (Research Committees) IPSA. Na ogólną liczbę 51 funkcjonujących w IPSA takich komitetów przedstawiciele Polski w trzech przypadkach zostali wybrani na przewodniczących, a w czterech przypadkach była to funkcja wiceprzewodniczącej/ wiceprzewodniczącego (zob. Załącznik nr 2). Poza tym byli wybierani do władz/zarządów Komitetów Badawczych (brak jest dokładnych danych na ten temat).

Znaczącym polskim akcentem podczas Kongresu było przyznanie prof. Adamowi Przeworskiemu nagrody Juana Linza za wybitne osiągnięcia w badaniach nad decentralizacją wielonarodowościową i wieloetniczną integracją oraz w badaniach porównawczych nad federalizmem. Prof. A. Przeworski jest profesorem nauk politycznych na Uniwersytecie Nowy Jork.

Przede wszystkim należy podkreślić dużą aktywność naukowców polskich w przygotowanie sesji i paneli poszczególnych komitetów badawczych IPSA oraz ich aktywny udział w nich podczas Kongresu. Na podkreślenie zasługuje fakt bycia przewodniczącymi Sesji Programowych Kongresu (Congress Program Session Chairs), co wiązało się z przynajmniej kilkumiesięczną pracą jeszcze przed Kongresem ${ }^{11}$.

Warto również odnotować fakt, iż w trakcie Kongresu jedenaście razy polscy badacze byli przewodniczącymi paneli, a w jednym przypadku byli zgłoszeni jako współprzewodniczący (zob. Załącznik nr 3). Rolę dyskutanta pełnili w 8 (6) przypadkach (zob. Załącznik nr 4). Znaczna liczba polskich badaczy przygotowała referaty na Kongres - 52 referaty (zob. Załącznik nr 5), w tym: dziewięć referatów dwóch polskich autorów, jeden referat trzech polskich autorów i dwa referaty jednego polskiego i jednego zagranicznego autora oraz jeden referat dwóch polskich i jednego zagranicznego autora, co pozytywnie ukazuje postępującą internacjonalizację polskich badaczy

10 Zob. więcej: IPSA 25th Executive Committee (2018-2020). Pobrane z: http://www.ipsa. org/news/news/ipsa-25th-executive-committee-2018-2020.

11 Byli nimi: Mikołaj Cześnik, Maria Marczewska-Rytko, Krzysztof Ostrowski, Łukasz Zamęcki i Bartłomiej Zdaniuk. 
w porównaniu z wcześniejszymi Kongresami IPSA. Tendencją stało się coraz częściej przygotowywanie referatów współautorskich.

Warto też podkreślić, że część polskich badaczy występowała na Kongresie w kilku rolach - organizatora sesji i paneli, przewodniczącego panelu, dyskutanta i referenta ${ }^{12}$. Siedmiu badaczy głosiło dwa referaty - pięciu jeden autorski, a jeden współautorski ${ }^{13}$ oraz $\mathrm{w}$ dwóch przypadkach dwukrotnie autorski ${ }^{14}$. Aktywność tę należy docenić.

Nowym zjawiskiem jest fakt, że w trzech przypadkach referaty zostały przygotowane przez autorów zagranicznych związanych z polskimi instytucjami naukowymi, a także w jednym przypadku autorami referatu było dwóch zagranicznych naukowców.

Podsumowując, mimo olbrzymiej odległości z Polski do Australii i wysokich kosztów lotu oraz pobytu, udział polskiej politologii w 25. Światowym Kongresie IPSA w Brisbane w 2018 r. można uznać za pozytywny, zarówno pod względem wyborów do władz IPSA i jej komitetów badawczych, a przede wszystkim w kontekście organizacji sesji i paneli oraz ich aktywnego, a przy tym merytorycznego udziału.

\section{PROF. DR HAB. ARKADIUSZ ŻUKOWSKI}

Przewodniczący Polskiego Towarzystwa Nauk Politycznych

Instytut Nauk Politycznych

Wydział Nauk Społecznych

Uniwersytet Warmińsko-Mazurski

ul. Szrajbera 11, 10-561 Olsztyn

arkadiusz.zukowski@uwm.edu.pl

12 Dla przykładu: Maria Marczewska-Rytko jako organizator sesji i paneli, przewodniczący panelu, dyskutant i referent; Mikołaj Cześnik jako organizator sesji i paneli, przewodniczący panelu, dyskutant i referent; Adam Szymański jako przewodniczący panelu, dyskutant (dwukrotnie) i referent (dwukrotnie); Anna Sroka jako przewodniczący panelu (dwukrotnie) i referent.

13 Byli nimi: Bartosz Hordecki, Paulina Pospieszna, Barbara Kratiuk, Aleksandra Wagner, Przemysław Żukiewicz.

14 Byli nimi: Urszula Zawadzka-Pak, Adam Szymański. 


\section{Bibliografia}

IPSA 25th Executive Committee (2018-2020). Pobrane z: http://www.ipsa.org/news/ news/ipsa-25th-executive-committee-2018-2020.

2018 Post-Congress Report: 25th IPSA World Congress in Brisbane 2018. (2018). Montreal.

\section{Załącznik nr 1}

Lista uczestników z Polski podczas Kongresu IPSA w Brisbane w 2018 r. The list of Polish participants during the IPSA Congress in Brisbane, 2018 Список участников из Польши во время Конгресса IPSA в Брисбене в 2018 году

\begin{tabular}{|r|l|l|l|}
\hline Lp. & Imię & Nazwisko & Instytucja \\
\hline 1 & Andrzej & Antoszewski & Uniwersytet Wrocławski \\
\hline 2 & Agnieszka & Bejma & Uniwersytet Warszawski \\
\hline 3 & Beata & Bochorodycz & Uniwersytet Adama Mickiewicza w Poznaniu \\
\hline 4 & Mikołaj & Cześnik & SWPS Uniwersytet Humanistycznospołeczny \\
\hline 5 & Jarosław Filip & Czub & Uniwersytet Warszawski \\
\hline 6 & Mateusz & Danielewski & Uniwersytet Warszawski \\
\hline 7 & Tadeusz & Dmochowski & Uniwersytet Gdański \\
\hline 8 & Rafał & Dudała & Uniwersytet Jana Kochanowskiego w Kielcach \\
\hline 9 & Artur & Gruszczak & Uniwersytet Jagielloński \\
\hline 10 & Bartosz & Hordecki & Uniwersytet Adama Mickiewicza w Poznaniu \\
\hline 11 & Małgorzata & Kaczorowska & Uniwersytet Warszawski \\
\hline 12 & Paulina & Kalina & Fundacja Instytut Nauki o Polityce \\
\hline 13 & Magdalena & Kania & Uniwersytet Jagielloński \\
\hline 14 & Agnieszka & Kasińska-Metryka & Uniwersytet Jana Kochanowskiego w Kielcach \\
\hline 15 & Adam & Kirpsza & Uniwersytet Jagielloński \\
\hline 16 & Tomasz & Komornicki & $\begin{array}{l}\text { Instytut Geografii i Przestrzennego Zagospoda- } \\
\text { rowania, Polska Akademia Nauk }\end{array}$ \\
\hline 17 & Barbara & Kratiuk & Uniwersytet Warszawski \\
\hline 18 & Grzegorz & Makowski & Collegium Civitas \\
\hline 19 & Maria & Marczewska-Rytko & $\begin{array}{l}\text { Uniwersytet Marii-Curie Skłodowskiej } \\
\text { w Lublinie }\end{array}$ \\
\hline & & \\
\hline
\end{tabular}




\begin{tabular}{|c|c|c|c|}
\hline Lp. & Imię & Nazwisko & Instytucja \\
\hline 20 & Patrycja & Matusz-Protasiewicz & Uniwersytet Wrocławski \\
\hline 21 & Renata & Mieńkowska-Norkiene & Uniwersytet Warszawski \\
\hline 22 & Magdalena & Musiał-Karg & Uniwersytet Adama Mickiewicza w Poznaniu \\
\hline 23 & Olga & $\begin{array}{l}\text { Nadskakuła- } \\
\text {-Kaczmarczyk }\end{array}$ & Uniwersytet Mikołaja Kopernika w Toruniu \\
\hline 24 & Jarosław & Nocoń & Uniwersytet Gdański \\
\hline 25 & Wojciech & Nowiak & Uniwersytet Adama Mickiewicza w Poznaniu \\
\hline 26 & Mikołaj & Pawlak & Uniwersytet Warszawski \\
\hline 27 & Dorota & Piontek & Uniwersytet Adama Mickiewicza w Poznaniu \\
\hline 28 & Grzegorz & Piwnicki & Uniwersytet Gdański \\
\hline 29 & Paulina & Pospieszna & Uniwersytet Adama Mickiewicza w Poznaniu \\
\hline 30 & Kateryna & Pryshchepa & Kolegium Europejskie w Natolinie \\
\hline 31 & Zdzisław W. & Puślecki & Uniwersytet Adama Mickiewicza w Poznaniu \\
\hline 32 & Agnieszka & Rothert & Uniwersytet Warszawski \\
\hline 33 & Michał & Rydz & Uniwersytet Warszawski \\
\hline 34 & Rafał & Smoczyński & Polska Akademia Nauk \\
\hline 35 & Anna M. & Sroka & Uniwersytet Warszawski \\
\hline 36 & Andrzej & Stelmach & Uniwersytet Adama Mickiewicza w Poznaniu \\
\hline 37 & Jarosław & Szczepański & Fundacja Instytut Nauki o Polityce \\
\hline 38 & Adam & Szymański & Uniwersytet Warszawski \\
\hline 39 & Aleksandra & Wagner & Uniwersytet Jagielloński \\
\hline 40 & Tadeusz & Wallas & Uniwersytet Adama Mickiewicza w Poznaniu \\
\hline 41 & Iwona & Wrońska & Uniwersytet Jana Kochanowskiego w Kielcach \\
\hline 42 & Karol & Żakowski & Uniwersytet Łódzki \\
\hline 43 & Łukasz & Zamecki & Uniwersytet Warszawski \\
\hline 44 & Urszula & Zawadzka-Pak & Uniwersytet w Białymstoku \\
\hline 45 & Bartłomiej & Zdaniuk & Brak afiliacji \\
\hline 46 & Olga & Zelinska & $\begin{array}{l}\text { Instytut Filozofii i Socjologii, Polska Akademia } \\
\text { Nauk }\end{array}$ \\
\hline 47 & Przemysław & Żukiewicz & Uniwersytet Wrocławski \\
\hline 48 & Arkadiusz & Żukowski & Uniwersytet Warmińsko-Mazurski w Olsztynie \\
\hline
\end{tabular}

Źródło: dane Sekretariatu IPSA. 


\section{Załącznik nr 2}

Polki i Polacy we władzach Komitetów Badawczych IPSA - wybrani podczas Kongresu IPSA w 2018 r. Poles in the power of IPSA Research Committees-elected during the IPSA Congress in 2018 Польки и поляки во властях Исследовательских Комитетов IPSA избранные во время Конгресса IPSA в 2018 году

\begin{tabular}{|l|l|l|l|}
\hline $\begin{array}{l}\text { Numer } \\
\text { Komitetu } \\
\text { Badawczego }\end{array}$ & Nazwa Komitetu Badawczego & Imię i nazwisko & Funkcja \\
\hline RC12 & Biology and Politics & Jerzy Wiatr & $\begin{array}{l}\text { Wiceprzewod- } \\
\text { niczący }\end{array}$ \\
\hline RC13 & $\begin{array}{l}\text { Democratization in Comparative } \\
\text { Perspective }\end{array}$ & Bartłomiej Zdaniuk & Przewodniczący \\
\hline RC13 & $\begin{array}{l}\text { Democratization in Comparative } \\
\text { Perspective }\end{array}$ & Adam Szymański & $\begin{array}{l}\text { Wiceprzewod- } \\
\text { niczący }\end{array}$ \\
\hline RC16 & Socio-Political Pluralism & Mikołaj Cześnik & Przewodniczący \\
\hline RC21 & $\begin{array}{l}\text { Political Socialization and } \\
\text { Education }\end{array}$ & $\begin{array}{l}\text { Maria } \\
\text { Marczewska-Rytko }\end{array}$ & $\begin{array}{l}\text { Wiceprzewod- } \\
\text { nicząca }\end{array}$ \\
\hline RC34 & Quality of Democracy & Anna M. Sroka & $\begin{array}{l}\text { Wiceprzewod- } \\
\text { nicząca }\end{array}$ \\
\hline RC42 & $\begin{array}{l}\text { Security, Integration and } \\
\text { Unification }\end{array}$ & Marceli Burdelski & $\begin{array}{l}\text { Wiceprzewod- } \\
\text { niczący }\end{array}$ \\
\hline RC47 & Local-Global Relations & Krzysztof Ostrowski & Przewodniczący \\
\hline
\end{tabular}

Źródło: dane Sekretariatu IPSA. 


\section{Załącznik nr 3}

Lista polskich badaczy, którzy przewodniczyli panelom podczas Kongresu IPSA w Brisbane w 2018 roku

List of Polish researchers, who presided the side panels during the IPSA Congress in Brisbane in 2018

Список польских исследователей, которые председательствовали боковые панели во время Конгресса IPSA в Брисбене в 2018 году

1. OCIS06.06 Critical Geopolitics and New Security Challenges, Chair Gruszczak, Artur - Jagiellonian University,

2. GS12.13 Figuring out the Flaming Borders: the South Asian Borders in Culture, History and Geopolitics, Chair Sroka, Anna M. - University of Warsaw,

3. RC34.05 The Impact of Political Extremism on Quality of Democracy in Contemporary World Sunday, Chair Sroka, Anna M. - University of Warsaw,

4. RC03.03 Differentiated Integration in the European Union - Consequences for Relations with Neighbours, Chair Szymanski, Adam - University of Warsaw,

5. RC34.06 The Political Parties at The Crossroads: Borders and Margins. The Challenges Facing Political Parties in Context of Quality of Democracy in The Modern World, Chair Kaczorowska, Małgorzata - University of Warsaw,

6. RC16.02 Pluralism in the Modern World: Developments, Opportunities, Challenges, Threats, Chair Cześnik, Mikołaj - SWPS University of Social Sciences and Humanities,

7. RC21.06 Political Socialization and Civic Participation in the Context of Social Movements and Globalization Processes, Chair Marczewska-Rytko, Maria Maria Curie-Sklodowska University,

8. RC38.06 NGOs and Business in Policy-Making, Chair Czub, Jarosław Filip Institute of European Studies, University of Warsaw,

9. RC22.02 Elections and Political Communication, Chair Żukiewicz, Przemysław - University of Wrocław,

10. RC16.03 The 'New Theory of Pluralism', Chair Zamęcki, Łukasz - University of Warsaw,

11. RC21.08 Political Socialization, Citizenship and Globalization Processes, Chair Żukowski, Arkadiusz - University of Warmia and Mazury in Olsztyn. 


\section{Załącznik nr 4}

Lista polskich badaczy, którzy zostali zrejestrowani jako dyskutanci na Kongres IPSA w Brisbane w 2018 r. List of Polish researchers who were reissued as panellists at the IPSA Congress in Brisbane in 2018 Список польских исследователей, которые были переизданы как дискуссионные на Конгрессе IPSA в Брисбене в 2018 году

1. RC13.01 Democratization in Europe and Middle East

- Discussant Zdaniuk, Bartłomiej - No affiliation,

2. GS12.18 Hong Kong Twenty Years After Handover. Politics and Identity Under Reconstruction

- Discussant Zamęcki, Łukasz - University of Warsaw,

3. RC03.04 Economic Governance in the EU Post-crisis Tuesday,

- Discussant Szymański, Adam - University of Warsaw,

4. RC21.06 Political Socialization and Civic Participation in the Context of Social Movements and Globalization Processes

- Discussant Burdelski, Marceli ${ }^{15}$ - Polish Political Science Association,

5. RC13.05 Democratization in South Asia, Africa, and Latin

- Discussant Szymański, Adam - University of Warsaw,

6. RC21.09 Political Socialization: Challenges in the Modern World,

- Discussant Marczewska-Rytko, Maria - Maria Curie-Sklodowska University,

7. RC16.03 The 'New Theory of Pluralism'

- Discussant Cześnik, Mikołaj - SWPS University of Social Sciences and Humanities,

8. GS02.11 Inequality as a Global Problem and Peculiarities of Countries of BRICS: The Boundaries and Possibility of Regulation

- Discussant Sasińska-Klas, Teresa ${ }^{16}$ - Jagiellonian University.

Źródło: Program of the 25th World Congress of Political Science, 21-25 July 2018, Brisbane. Pobrane z: htps://wc2018.ipsa.org/sites/default/files/page/WC2018/Program/2018.06.26\%20FINAL\%20Program_web.pdf; Dane Sekretariatu IPSA.

\footnotetext{
15 Nie uczestniczył w Kongresie.

16 Nie uczestniczyła w Kongresie.
} 


\section{Załącznik nr 5}

Lista badaczy z Polski, którzy zgłosili referaty na Kongres IPSA

w Brisbane w 2018 r.

List of Polish researchers who submitted abstracts to the IPSA Congress

in Brisbane in 2018

\section{Список исследователей из Польши, которые подали доклады на Конгресс IPSA в Брисбене в 2018 году}

Kolejność zapisu listy jest następująca: numer komitetu badawczego i panelu, tytuł panelu, tytuł referatu i autor/autorzy, przynależność do instytucji naukowej.

RC01.07 New Concepts and Measures for the Study of Domestic Politics

- Political Triangle - Model of Political Spectrum Szczepański, Jarosław - University of Warsaw,

GS01.13 The Spread of Democratic Values

- Between Fair and Rigged. Elections as a Key Determinant of the 'Borderline Political Regime' - Turkey in Comparative Perspective Szymanski, Adam University of Warsaw,

RC13.01 Democratization in Europe and Middle East

- Poland at the Crosswords - Mechanisms of Politicizing Civic Sector Bejma, Agnieszka - University of Warsaw,

RC13.01 Democratization in Europe and Middle East

- Between Fair and Rigged. Elections as a Key Determinant of the 'Borderline Political Regime' - Turkey in Comparative Perspective Szymański, Adam University of Warsaw,

RC14.11 Ethnic Politics After Communism

- The Problem of Harmonization of Values and Interests in Relations between the European Union and Central Asian Countries Wallas, Tadeusz - Adam Mickiewicz University in Poznań Hordecki, Bartosz - Adam Mickiewicz University in Poznań,

GS01.13 The Spread of Democratic Values

- In Need for Democracy Assistance? Evaluating Youth Political Participation in Democratizing versus Democratic Countries Pospieszna, Paulina - Adam Mickiewicz University in Poznań, 
RC34.05 The Impact of Political Extremism on Quality of Democracy in Contemporary World

- Horizontal Accountability in Poland after 2015: Landscape after the Battle Sroka, Anna M. - University of Warsaw,

RC39.01 Comparing Welfare Systems

- Cultural and Social Assimilation of Immigrants, and Systemic Solutions - Poles in Norway and Ukrainians in Poland. From the Viewpoint of Comparative Studies

Nowiak, Wojciech - Adam Mickiewicz University in Poznań; Stelmach, Andrzej - Adam Mickiewicz University in Poznań,

RC50.04 The Politics of Language

- On Determining Borders and Frontiers of the Contemporary Russian Language

Policy Hordecki, Bartosz - Adam Mickiewicz University in Poznań, GS09.11 Policy Participation - Part 2

- Direct Democracy's Tools and Civic Participation in the Face of Use of Internet

Musiał-Karg, Magdalena - Adam Mickiewicz University in Poznań,

RC03.03 Differentiated Integration in the European Union - Consequences for Relations with Neighbours

- Changing Face Of Europe: Projected Impact on Europe's "Core" and "Periphery" Of Chinese FDI into the CEEC Region Jones, David A. ${ }^{17}$ - University of Warsaw, Liu, Hanzhen ${ }^{18}$ - Vistula University,

RC03.03 Differentiated Integration in the European Union - Consequences for Relations with Neighbours

- Chance for the Coordination of Activities in Foreign Policy? Szymański, Adam - University of Warsaw,

RC03.03 Differentiated Integration in the European Union - Consequences for Relations with Neighbours

- Neither Switzerland, Nor Way?: Europeanisation, the EFTA Experience and the Future Model of the UK-EU Relations after Brexit Biskup, Przemysław ${ }^{19}$ - The Polish Institute of International Affairs; Rydz, Michal - University of Warsaw, RC51.19 The Unequal Politics of Preferential Trade Agreements

- The Impact of the Rise Global Supply Chains on the Political Economy of Trade and Countries Motivations for Cooperating on Trade Policies Puślecki, Zdzisław W. - Adam Mickiewicz University in Poznań,

\footnotetext{
17 Nie uczestniczył w Kongresie.

18 Nie uczestniczył w Kongresie.

19 Nie uczestniczył w Kongresie.
} 
GS12.24 Jeju Peace Island for Koreas

- Papers Mass Media and Their Role in North Korean Propaganda Danielewski, Mateusz - University of Warsaw,

GS12.24 Jeju Peace Island for Koreas

- Let the Sun Shine? People-to-People Diplomacy in Inter-Korean Relations Ayhan, Kadir - Hankuk University of Foreign Studies, South Korea; Smoczyński, Rafał - Polish Academy of Sciences,

RC15.01 Bordering, Borderwork, Mobilities, Citizenship: Conceptual and Empirical Challenges for Border Research

- The Role of Polish Eastern Border in the Global Systems Komornicki, Tomasz - Institute of Geography and Spatial Organization, Polish Academy of Sciences; Wiśniewski, Rafal ${ }^{20}$ - Polish Academy of Sciences,

RC18.07 New Trends in Development and Economic Governance

- Constructed Communities: India's Engagement in South and Southeast Asia Kratiuk, Barbara - University of Warsaw; Jaskólska, Aleksandra ${ }^{21}$ - University of Warsaw,

GS12.23 Japanese Populism in a Comparative Context

- Papers Strategic Use of Premature Elections in Japan: Comparison of the Koizumi and Abe Cabinets Żakowski, Karol - University of Lodz,

GS03.28 New Directions in Foreign Policy Analysis

- Papers Divided Europe? EU Member States' Interests and EU Decision-making Process Behind Sanctions against Russia Pospieszna, Paulina - Adam Mickiewicz University in Poznań; Portela, Clara - Universitat de València, Spain; Skrzypczyńka, Joanna ${ }^{22}$ - Adam Mickiewicz University in Poznań,

GS03.28 New Directions in Foreign Policy Analysis

- Tug o’ War: Vietnam's Strategy for Survival between Great Powers Kratiuk, Barbara - University of Warsaw,

RC05.09 Metropoles

- Papers Accommodation, Transformation, Inertia. Model of Transfer of Rules and Norms from the PRC to the HKSAR and Adjustment of Hong Kong Society Zamęcki, Lukasz - University of Warsaw,

RC05.09 Metropoles

\footnotetext{
20 Nie uczestniczył w Kongresie.

21 Nie uczestniczyła w Kongresie.

22 Nie uczestniczyła w Kongresie.
} 
- How Immigrant Integration Policies in Central-Eastern Europe Metropolises Highlight a European Frame of Integration Policy Matusz-Protasiewicz, Patrycja - University of Wrocław; Pawlak, Mikołaj - University of Warsaw, RC08.03 Governing, Representation and Democracy

- To Package, or Not to Package? Explaining Issue Linkage in the European Union Lawmaking Kirpsza, Adam - Jagiellonian University,

RC12.01 Biopolicy and Social Justice

- Governance, Resilience and Neurobiology. Lessons for Conflicted Societies Rothert, Agnieszka - University of Warsaw,

RC15.10 Territory, Sovereignty and Political Identity

- Ethnopolitics Is Back! The Politics of Border Management of the Visegrad Four Gruszczak, Artur - Jagiellonian University,

RC21.06 Political Socialization and Civic Participation in the Context of Social Movements and Globalization Processes

- Papers National Referendum as a Part of Civic Participation in Central and Eastern Europe after 1989 Marczewska-Rytko, Maria - Maria Curie-Sklodowska University,

RC21.06 Political Socialization and Civic Participation in the Context of Social Movements and Globalization Processes

- Citizen's Right to Vote - Contemporary Tendencies in Global World Żukowski, Arkadiusz - University of Warmia and Mazury in Olsztyn,

RC21.06 Political Socialization and Civic Participation in the Context of Social Movements and Globalization Processes

- Populism and the Media in Poland: Journalists' Attitudes towards Populist Political Actors Piontek, Dorota - Adam Mickiewicz University in Poznań; Stępińska, Agnieszka ${ }^{23}$ - Adam Mickiewicz University in Poznań,

RC33.04 Political Science and Politics: Comparative Perspectives on Disciplinary Autonomy

- International Relations in the Frist Half of the Twentieth Century Pugacewicz, Tomasz - Jagiellonian University,

RC38.06 NGOs and Business in Policy-Making

- Inequality in Access to EU Institutions by Business Groups and NGOs Czub, Jarosław Filip - Institute of European Studies, University of Warsaw,

RC51.07 Les diplomates engloutis? L'art diplomatique dans un environnement concurrentiel

23 Nie uczestniczyła w Kongresie. 
- La démocratisation renforce-t-elle les États? Zdaniuk, Bartłomiej - No affiliation, Poland, Biskup, Przemyslaw ${ }^{24}$ - The Polish Institute of International Affairs,

IAPSS.05 Europe's Multiple Borders: Critical Investigations

- Implementing the logic of Multi-level Governance to Development Assistance. Towards Decentralized Cooperation in the EU Development Assistance Policy. Kania, Magdalena - Jagiellonian University,

AUS04.01 Accountability, Integrity \& 21st Century Constitutionalism: The AusPSA Presidential Panel

- Montesquieu and Illiberal Democracy - Simulacra and Reality of Separation of Powers Makowski, Grzegorz - Collegium Civitas,

RC11.03 Sustainable Energy Transformation in an Age of Post-truth Politics, Protectionism, Populism, and Local Resistance

- Anatomy of Disbelief: Explaining Polish Climate Scepticism Maltby, Tomas King's College London, United Kingdom; Wagner, Aleksandra - Jagiellonian University,

RC11.03 Sustainable Energy Transformation in an Age of Post-truth Politics, Protectionism, Populism, and Local Resistance

- Future of the World. Future Visions in Energy-related Discourses on the Example of Polish Public Debate of Energy Policy Wagner, Aleksandra - Jagiellonian University,

RC47.03 Personalisation of Politics and Political Leadership in Central and Eastern Europe - What are the Consequences for Democratic Consolidation?

- Papers Political leaders in a network model of the cabinet coalition formation. Case study Żukiewicz, Przemysław - University of Wrocław; Antoszewski, Andrzej - University of Wrocław,

RC47.03 Personalisation of Politics and Political Leadership in Central and Eastern Europe - What are the Consequences for Democratic Consolidation?

- New Models of Political Leadership in the Times of Crisis (Poland and Spain - A Comparative Analysis) Kasińska-Metryka, Agnieszka - Jan Kochanowski University,

RC47.03 Personalisation of Politics and Political Leadership in Central and Eastern Europe - What are the Consequences for Democratic Consolidation?

- Leadership at the Age of Populism: A Comparison Between the Political Leaders of Italy and Poland Dudala, Rafał - Jan Kochanowski University,

24 Nie uczestniczył w Kongresie. 
GS02.05 EU and its Discontents

- Can Democracy Harm Public Finance? Comparative Study of European Countries Zawadzka-Pak, Urszula - University of Bialystok,

GS02.05 EU and its Discontents

- Canadian and Australian Immigration Policies and the Protection of Human Rights Wrońska, Iwona - Jan Kochanowski University,

RC22.05 Political Communication: Case studies

- Better European Union's Communication Policy - A Panacea to the EU Identity Crisis Mieńkowska-Norkiene, Renata - University of Warsaw,

RC23.12 Party Organization

- Who holds the keys? Polish Political Parties: their members and leaders. An Assessment of their Impact on Intra-Party Democracy Kaczorowska, Małgorzata - University of Warsaw,

RC05.03 Local Elections

- Elections in the Amalgamated Territorial Communities and establishment of the local politics in Ukraine Pryshchepa, Kateryna - College of Europe Natolin Campus; Kowal, Pawel ${ }^{25}$ - Institute of Political Studies of the Polish Academy of Sciences,

GS03.48 The Future of Asian Security

- Between Local and International Politics: Governor Onaga and the Issue of the US Military Bases in Okinawa Bochorodycz, Beata - Adam Mickiewicz University in Poznań,

GS09.12 Protest Movements - Part 1

- Papers Anti-Government Protests and Political Capital of Non-Systemic Opposition in Russia Nadskakuła-Kaczmarczyk, Olga - Nicolaus Copernicus University,

GS09.12 Protest Movements - Part 1

- Ecological Conditions of Local Maidans in Ukraine Zelinska, Olga - The Graduate School for Social Research, Polish Academy of Sciences,

GS09.12 Protest Movements - Part 1

- Discourse of Russian Protests of 2017: A Multimodal Semiotic Analysis Fomin, Ivan $^{26}$ - Nicolaus Copernicus University,

GS09.10 Policy Participation - Part 1

\footnotetext{
25 Nie uczestniczył w Kongresie.

26 Nie uczestniczył w Kongresie.
} 
- Papers Participatory Budgeting as the Instrument of Strengthening or Weakening Democratic Public Values? Case Study of Poland Zawadzka-Pak, Urszula University of Bialystok,

RC21.08 Political Socialization, Citizenship and Globalization Processes

- The Role of Socialization in the Process of Forming a Political Culture Nocoń , Jarosław - University of Gdańsk; Piwnicki, Grzegorz - University of Gdańsk; Dmochowski, Tadeusz - University of Gdańsk,

RC42.04 Dealing with North Korea - The Challenges for US-Foreign Policy

- The Confrontation United States with North Korea. History, Present and Future Burdelski, Marceli ${ }^{27}$ - Polish Political Science Association.

Źródło: Program of the 25th World Congress of Political Science, 21-25 July 2018, Brisbane. Pobrane z: htps://wc2018.ipsa.org/sites/default/files/page/WC2018/Program/2018.06.26\%20FINAL\%20Program_web.pdf; Sekretariat IPSA.

27 Nie uczestniczył w Kongresie. 